\title{
МЕДИКО-СОЦІАЛЬНЕ ДОСЛІДЖЕННЯ РІВНЯ ОБІЗНАНОСТІ МЕДИЧНОГО ПЕРСОНАЛУ ПРО ГЕСТАЦЙНИЙ ДІАБЕТ
}

\author{
O. Т. Борачок
}

\author{
Львівський медичний коледж
}

У статті наведено результати медико-соціального дослідження, а саме анкетування, існуючого рівня обізнаності та поінформованості медичного персоналу про таке захворювання, як гестаційнпй діабет.

\section{MEDICAL AND SOCIAL RESEARCH OF MEDICAL STAFF KNOWLEDGE ABOUT GESTATIONAL DIABETES}

\section{O. T. Borachok \\ Lviv medical college}

The results of medical and social research, such as surveys, existing awareness and awareness of medical personnel about such diseases as gestational diabetes.

Вступ. Гестаційний діабет (ГД) - це порушення толерантності до глюкози будь-якого ступеня, що виникає під час вагітності й зникає після пологів [1]. За даними Всесвітньої організації охорони здоров'я, поширеність цього захворювання серед вагітних жінок становить $3 \%$. Тому можна вважати доведеним, що не менш ніж троє жінок із кожних 100 вагітних переносять ГД, і якщо його поширеність у країні (регіоні) $\epsilon$ нижчою, це свідчить про недостатнє виявлення захворювання [2, 3]. Встановлення ступеня обізнаності медичних сестер, які безпосередньо працюють чи будуть працювати з такими пацієнтками і стало метою даного дослідження.

Основна частина. 3 метою оцінки поінформованості та обізнаності про дане захворювання для медичного персоналу, а саме медичних сестер сімейного лікаря, акушерок, які працюють в жіночій консультації, також студентів-випускників (медичних сестер-бакалаврів) була розроблена анкета, яка включала такі питання: «Що таке гестаційний діабет», фізіологічні зміни вуглеводного обміну під час вагітності, які гормони мають сильний, середній та слабкий діабетогенний вплив, чинники розвитку гестаційного діабету, коли (в якому терміні вагітності) проводять скринінг на ГД у жінок без факторів ризику та хоча 6

๑ О. Т. Борачок, 2015 з одним фактором ризику, показання до термінового обстеження на ГД (крім наявності факторів ризику), яким методом проводять скринінг на гд, техніку проведення та нормальні показники 1-годинного ПТ, показання до проведення та нормальні показники 3-годинного ГТТ, вплив ГД на новонародженого, здоров'я матері та віддаленні наслідки, методи лікування ГД, показання до дієтотерапії при ГД, калорійність добового раціону при ГД, показання до інсулінотерапії при ГД, особливості інсулінотерапії, критерії ефективності терапії ГД, оцінку стану плода при ГД, грудне вигодовування при гд, методи розродження при ГД, показання до кесаревого розтину при Гд та роль медсестри при догляді за вагітною з ГД.

На базі Львівського медичного коледжу та Городоцької центральної районної лікарні, було проведено анонімне анкетування 60 респондентів.

Більшість, а саме понад 90 \% опитаних, знає, що таке гестаційний діабет, та майже всі, 98 \%, знають, яка норма глікемії у здорової людини.

Проте щодо блоку питань, котрі базуються на фізіологічних змінах в організмі жінки, які провокують розвиток даного захворювання, та гормонах, які мають діабетогенний вплив - 17 осіб (28\%) взагалі не вказали правильної відповіді, 29 (48 \%) вказували правильну відповідь не повністю, і лише 14 (23\%) респондентів дали правильні відповіді. 
На запитання про чинники розвитку гестаційного діабету 56 людей (93 \%) вказали правильну відповідь родинний анамнез, ГД при попередній вагітності та ожиріння, з них 10 (16 \%) вказали на великий плід в анамнезі та багатоводдя, 17 (28 \%) - зазначили глюкозурію і 5 (8\%) - мертвонародження в анамнезі.

На запитання, які стосуються скринінгу, респонденти відповіли так: 53 (88 \%) зазначили правильну відповідь - термін проведення даної маніпуляції у 24-28 тижнів без факторів ризику та хоча 6 з одним фактором. Показання до термінового обстеження на ГД - 52 (86 \%) вказали на глікемію натще у плазмі венозної крові більше 5,83 ммоль/л, у цільній капілярній крові більше 5,0 ммоль/л.

Щодо методів скринінгу та техніки проведення 1- та 3-годинного глюкозотолерантного тесту відповіді були такі: яким методом проводять скринінг - 48 (80\%) вказали годинний тест толерантності до глюкози, техніка проведення 1-годинного ПТ - 56 (93 \%) зазначили відповідь 50 г глюкози розчиненої у 200 мл води, отримання результатів через 1 годину. Техніка проведення 3-годинного ГТТ - 45 (75\%) вагітних випивають 100 г глюкози, розчиненої у 250 мл води з додаванням лимонного соку, рівень глікемії визначається перед прийманням, через 1, 2 та 3 год. Показання до проведення 3-годинного Пт 38 (63 \%) - глікемія більше 7,8 ммоль/л при проведенні годинного тесту толерантності до глюкози, та нормальні показники 3-годинного ПТ - 31 (51 \%) натще менше 5,83 ммоль/л, 1 год менше 10,55 ммоль/л, 2 год менше 9, 16 ммоль/л, 3 год менше 8,05 ммоль/л.

\section{ЛITEPATУРА}

1. Медвідь В. І. Цукровий діабет у вагітних: особливості проблеми в Україні / В. І. Медвідь // Ендокринологія. 2003. - № 1. - С. 4-9.

2. Медвідь В. І. Цукровий діабет і вагітність / В. І. Медвідь, Л. М. Викова. - К. : ЗАТ «|ндар»», 2004. - 8 с.
Наступний блок питань анкети стосувався впливу гестаційного діабету на плід, дитину, матір та його віддалені наслідки. Лише 12 осіб (20 \%) вказали правильно всі ускладнення як з боку матері, так і дитини.

Більшість опитуваних - 51 (85 \%) - знала про методи лікування ГД (дієтотерапія та інсулінотерапія), та попри це майже половина анкетованих не знає про показання до дієтотерапії та правильне харчування при дотриманні дієти.

Показання до інсулінотерапії - правильну відповідь вказало 29 осіб (48 \%). Особливості інсулінотерапії та критерії ефективності терапії ГД - 46 (76\%).

Оцінка стану плода при ГД та грудне вигодовування при Гд, відповідно, 27 (45 \%) і 41 (68 \%).

На запитання про метод розродження при ГД правильну відповідь дали 50 осіб (83 \%), показання до кесаревого розтину 54 респонденти (90\%). Та на останнє запитання про роль медичної сестри при догляді за вагітною з Гд правильно відповіли майже всі опитані - 59 (98\%).

Висновки. Базуючись на отриманих даних, більшість опитуваних медичних сестер, студентів та акушерок ознайомлені з гестаційним діабетом, але досить погано знають про фізіологічні зміни в організмі жінки під час вагітності, про гормони, які мають діабетогенний вплив, про вплив ГД на дитину і плід та дієтотерапію.

Для поліпшення ефективності лікування гестаційного діабету недостатньо знати лише основні критерії захворювання, а й потрібно розуміти, який його вплив і як з ним боротися.

3. Pregnancy outcomes in women with gestational diabetes compared with general obstetric population / B. M. Casey, M. I. Lucas, D. D. McIntire, K. I. Leveno // Obstet. Gynaecol. 1997,90, № 6, 869-873. 


\section{ДО УВАГИ АВТОРІВ!}

При підготовці матеріалів до журналу просимо дотримуватись таких вимог:

1. Стаття повинна містити дані про посаду, науковий ступінь і вчене звання кожного автора, а також прізвище, ім'я, по батькові, адресу, е-таї, телефон і факс автора, з яким можна вести листування і переговори.

2. Надсилати необхідно 2 примірники статті, надруковані на стандартному аркуші формату A4, шрифт «Times New Roman», poзмір шрифту 14, інтервал - 1,5. Поля: верхне - 20 мм, нижне - 25 мм, ліве - 30 мм, праве - 10 мм. Обсяг оригінальної статті, виключно рисунки, літературу, резюме, не повинен перевищувати 8-10 сторінок, обсяг огляду літератури 12 сторінок машинопису, короткого повідомлення - 3-5 сторінок. Електронний варіант статті необхідно надсилати у форматах *.doc, *. rtf, *. docx на CD. У статтях повинна застосовуватись система одиниць Cl.

3. Таблиці повинні бути надруковані в текстовому редакторі «Word 6.0, 7.0» по тексту статті та оформлені таким чином:

Таблиця 1. Назва таблиці.

4. Рисунки мають бути встановленими у текст статті й окремо подані у форматах JPG, TIF, CDR та оформлені таким чином:

Рис. 1. Підпис до рисунка.

5. При посиланні на публікацію ї̈ номер, згідно зі списком літератури, слід вказати у квадратних дужках.

6. Статтю викладати за такою схемою:

УДК

НАЗВА СТАТТІ (великими літерами, напівжирний шрифт) українською мовою.

Ініціали та прізвища авторів (малими літерами, напівжирний шрифт) українською мовою.

Назва установи, місто (малими літерами, курсив, напівжирний шрифт) українською мовою.

Резюме українською мовою.

НАЗВА СТАТТІ (великими літерами, напівжирний шрифт) англійською мовою.

Ініціали та прізвища авторів (малими літерами, напівжирний шрифт) англійською мовою.

Назва установи, місто (малими літерами, курсив, напівжирний шрифт) англійською мовою.

Резюме англійською мовою.

Вступ (з абзацу). У вступі слід у загальному вигляді окреслити постановку проблеми, зробити аналіз останніх досліджень та публікацій, в яких започатковано розв'язання даної проблеми, та виділити раніше не вирішені частини загальної проблеми, якій присвячена стаття; сформулювати мету і завдання роботи.

Основна частина (з абзацу).

висновки (з абзацу)

Література.

Список літератури подається в порядку цитування та відповідно до вимог, наведених у Бюлетені ВАКу № 5, 2009 р., зокрема:

- cmammi:

1. Котвіцька А. А. Наукові підходи щодо моделювання розвитку соціальної політики у сфері лікарського забезпечення населення / А. А. Котвіцька // Запорізький медичний журнал. - 2008. - № 2. - С. 157-161. (1 автор)

2. Немченко А. С. Дослідження соціальних чинників, що впливають на поширення наркоманії на регіональному рівні / А. С. Немченко, А. А. Котвіцька // Клінічна фармація. - 2007. - Т. 11, № 4. - С. 30-34. (2 автори)

3. Валькман Ю. Р. Моделирование НЕ-факторов - основа интеллектуализации компьютерных технологий / Ю. Р. Валькман, В. С. Быков,

А. Ю. Рыхальский // Системні дослідження та інформаційні технології. - 2007. - № 1. - С. 39-61. (3 автори)

4. Пролонгатори ліків на основі полімерних гідрогелів / В. Й. Скорохода, Ю. А. Мельник, Н. Б. Семенюк [та ін.] // Фармацевтичний часопис. -

2009. - № 3. - С. 25-29. (бiльше 3 qөmopie)

- ducepmayii:

5. Демченко В. О. Організаційно-економічні дослідження зі створення лікарських засобів серцево-судинної дії та розробка технології таблеток

ніфедипіну з полімерною оболонкою : дис. ... кандидата фарм. наук : 15.00 .01 / Демченко Валерій Олегович. - Запоріжжя, 1997. - 180 с.

- аєтореферати дисертацій:

6. Головкін В. В. Біофармацевтичне обгрунтування складу, технології та дослідження м'яких інтравагінальних лікарських форм з мефенаміну натрієвою сіллю та мебетізолом : автореф. дис. на здобуття наук. ступеня канд. фармац. наук : спец. 15.00 .01 / В. В. Головкін. - Львів, 1997. - 18 с.

- авторські свідоцтва:

7. А. с. 1458020 СССР, МКИ³ ВО 5 С 9/06. Аппарат для нанесения пленочных покрытий на твердые лекарственные формы в псевдоожиженном слое / И. А. Демчук, Р. А. Беряк, Я. А. Максимович (СССР). - № 3360576/29-08; заявл. 1.10.85; опубл. 30.03.86, Бюл. № 11.

- nameнmu:

8. Пат. 54177 А Україна. 7 А61 К31/00. Стоматологічні плівки антивірусної дії «Віруплен» / Коритнюк Р. С., Давтян Л. Л., Коритнюк О. Я., Дзю-

бан Н. Ф., Петюнін Г. П. ; заявл. 31.05 .2002 ; опубл. 17.02.2003, Бюл. № 2.

- книги:

9. Бродский В. 3. Введение в факторное планирование эксперимента / В. З. Бродский. - М. : Наука, 1976. - 224 с. (1 автор)

10. Суберляк О. В. Технологія переробки полімерних та композиційних матеріалів : підруч. [для студ. вищ. навч. закл.] / О. В. Суберляк,

П. І. Баштанник. - Львів : Растр-7, 2007. - 375 с. (2 автори)

11. Лапач С. Н. Статистичні методи в медико-біологічних дослідженнях з використанням EKCEL / С. Н. Лапач, А. В. Губенко, П. Н. Бабич. - К. : Моріон, 2001. - 408 с. (3 автори)

12. Методика нормування ресурсів для виробництва продукції рослинництва / [Вітвіцький В. В., Кисляченко М. Ф., Лобастов І. В., Нечипорук А. А.]. - К. : НДІ «Украгропромпродуктивність», 2006. - 106 с. - (Бібліотека спеціаліста АПК. Економічні нормативи). (4 автори)

13. Психология менеджмента / [Власов П. К., Липницкий А. В., Ялущихина И. М. и др.]; под ред. Г. С. Никифорова. - [3-е изд.]. - Х. : Гуманитар. центр, 2007. - 510 с. (5 і більше авторів)

- матеріали конференцій, зт̈здів:

14. Корнієвська В. Г. Оптимальні терміни заготівлі сировини валеріани / В. Г. Корнієвська, М. С. Фурса, Ю. І. Корнієвський // Науково-технологічний процес і оптимізація технологічних процесів створення лікарських препаратів: міжнар. наук.-практ. конф., 6-7 квіт. 2006 р. : матеріали конф. -

Тернопіль : Укрмедкнига, 2006. - С. 40.

7. Редакція залишає за собою право корекції, скорочення і виправлення статті.

8. Статті, оформлені без дотримання наведених правил, не реєструються. Насамперед друкуються статті передплатників журналу, а також матеріали, що замовлені редакцією.

9. Автор несе повну відповідальність за достовірність даних, наведених у статті, й списку літератури.

10. Статті надсилати на адресу: редакція журналу «Медсестринство», видавництво двНЗ «Тернопільський державний медичний університет імені І. Я. Горбачевського МОЗ України», майдан Волі, 1, 46001, Тернопіль, Україна.

Тел.: (0352) 43-49-56; 430927. E-mail: journaltdmy@gmail.com, yastremska@tdmu.edu.ua

11. Окремим електронним файлом (для розміщення на сайті фурналу) потрібно надсилати розширене резюме англійською мовою об'ємом до двох сторінок, яке повинно містити ті ж структурні елементи, що й стаття (вступ, основна частина, висновки). 